\title{
What Do Young Intellectuals Look For in a Bank? An Empirical Analysis of Attribute Importance in Retail Bank Selection
}

\author{
Safiek Mokhlis (Corresponding author) \\ Faculty of Management and Economics, Universiti Malaysia Terengganu \\ 21030 Kuala Terengganu, Malaysia \\ Tel: 609-6684823 E-mail: safiek@umt.edu.my \\ Hayatul Safrah Salleh \\ Faculty of Management and Economics, Universiti Malaysia Terengganu \\ 21030 Kuala Terengganu, Malaysia \\ Nik Hazimah Nik Mat \\ Faculty of Management and Economics, Universiti Malaysia Terengganu \\ 21030 Kuala Terengganu, Malaysia
}

Received: June 4, 2011 Accepted: June 14, 2011 doi:10.5296/jmr.v3i2.701

\begin{abstract}
This study attempts to quantify the selection criteria used by university students in the process of selecting a bank to patronize. A quantitative methodology, using responses given by 482 Malaysia's undergraduates, is employed in the analysis. Friedman's nonparametric test for rank position and significance was performed to determine respondent's preferences and to see if the differences were significant. Results of the study suggest that students appear to be very concerned about the security aspects, ATM service and financial benefits when selecting a bank. Factors such as locational convenience and recommendation, which proved to be influential in previous studies, are no longer given with such importance.
\end{abstract}

Keywords: Attribute importance, Bank selection, University students, Malaysia 


\section{Introduction}

Increasing levels of competition in the Malaysian market for financial services has increased the need for retail banks to identify and attract new market segments. It is in this context that university students became a focus of attention in the bank market both as a source of new accounts and future profitability. Despite the fact that the majority of university students are unemployed and their 'earning' comes mainly from educational loans and parental contributions, they have become critical consumers for banks to pursue. The heightened importance of this group is due to several factors.

With the expansion of educational services in Malaysia, which tripled the number of university students in two recent decades (Economic Planning Unit, 2006), university or college students have become an important consumer market segment. The latest statistics reported by the Ministry of Higher Education Malaysia (2009) showed that the number of students entering local public universities for undergraduate studies rose dramatically from 29,962 in 2001 to 80,006 in 2009 - a $267 \%$ increase within a nine year period. The government's target to have at least $35 \%$ of the labor force with tertiary education should see the student markets will continue to trend upwards over the ensuing decade (Government of Malaysia, 2001).

University students are likely to need a bank account to negotiate their educational loans or parental contribution and may be obliged to administer their own personal financial affairs for the first time. Those who do not yet have bank accounts will need to open one as they started their studies because all grant providers pay allowances directly through students' bank accounts. Despite their relatively basic banking needs, students are to some degree a 'captive audience' and at the stage where they may be more responsive to marketing activities from financial institutions (Thwaites \& Vere, 1995).

Another important feature of the student market is the potential for above-average profitability in the future. Lewis (1982) commented that "the banks believed that it might well be in their interest to attract these young people to open accounts as they started college in the anticipation that they would remain, after graduation, with the bank and be profitable, in the long term, to that bank" (p. 63). The underlying logic of this comment is that college educated individuals have a significantly higher than average chance of rising from the low income group into the middle class (Duncan, Smeeding \& Rodgers, 1992). Specifically, as compared with nongraduates of the same age, graduates should normally secure more highly paid employment, to have a more progressive career and hence, develop a need for a wider range of financial services as they pass through their own life cycle (Tootelian \& Gaedeke, 1996).

Finally, it is interesting to note that the savings culture is much more extensive in Malaysia and some other Asian countries as compared to developed nations. Forecasted to close 2010 at nearly $50 \%$ of GDP, Malaysia's national savings rate is the third highest in the Asia Pacific region after China and Singapore and substantially higher than developed economies like those of the United States and the United Kingdom (Nielsen, 2010). Most parents would open savings accounts for their children when they were still very young so as to train them in the saving habit. This saving behavior continues as children enter teen years. A study by Sabri 
and Masud (2002) on financial socialization among university students in Malaysia found that adolescence started receiving allowances, have own accounts, make own savings and handle own expenses at an earlier age. Their study produced evidence to show that most students opened their bank accounts before arriving at college or university. It was found that, among a sample of university students, 36.3\% have own bank accounts opened whilst at primary school (aged 7-12) and 37.1\% whilst at secondary school (aged 13-17). Presumably, these "long-established" accounts will remain active when the children have grown up, indicating the potential of young consumers as a profitable target segment attractive to bank marketers.

As banks look to the future, university student is emerging as a key customer segment to engage. To establish positive and lasting relationships with this group of young intellectuals, banks will likely need to revisit many of their strategies, particularly along the dimensions of channels, marketing and products. First, however, they must develop an in-depth understanding of customers' attitudes and perceptions of the various attributes and the image which customers have of them. Bank marketers must therefore be able to answer these fundamental questions in their marketing attempts to young customers: why do students select a particular bank from a large number of alternatives? In evaluating the many options available to them, how would students come to a selection decision? On what criteria would they appraise their options? Answers to these questions should help bankers to see the need to develop more precise marketing strategies for attracting new customers and retaining existing ones.

With the intent to explore the choice preferences of university students in Malaysia with regard to retail bank selection, specific objectives of this study are: (1) to determine the criteria which young consumers select a retail bank; (2) to establish the rank of importance of the influencing factors in selecting a retail bank; and (3) to recommend marketing strategies for retail banks based on the needs and wants of the youngsters.

The remaining part of this article is structured in the following manner. Section 2 reviews the relevant literature on attribute importance in students' bank selection. A description of the methodology adopted in this study is discussed in Section 3. Section 4 presents the results, whilst a discussion of them is presented in Section 5. Finally, implications of the findings appear in Section 6.

\section{Attribute Importance in Retail Bank Selection}

In one of the earliest banking selection criteria studies, Lewis (1982) discovered that convenience of location to college and parental advice and influence were the predominant factors having a bearing on UK students' choice of bank. However, research by Thwaites and Vere (1995), conducted thirteen years later, showed that proximity of an ATM to college, free banking service and overall student offer were the top three selection criteria employed by college students in selecting which banks to patronize. In another study conducted by Tank and Tyler (2005), it was found that UK students placed greater importance on factors such as recommendations, reputation/image, level of interest rates, free cash incentives, and ease of account opening, in choosing a bank. Also of particular interest was that convenience factors, such as larger ATM network, proximity of branch and ATM to home/university, were all given low importance ratings. 
In the USA, three published studies are identified. In his article about American college students, Schram (1991) pointed out that convenience remains the primary reason why most college students choose their banks. Other than that, family tradition and loyalty to the banks seemed to be the important factors for college students. Meanwhile, Khazeh and Decker (1992-93) identified the following factors as the most important determinant attributes of bank selection decisions: service charge policy, reputation, interest charged on loans, quick loan approval and friendly tellers. Tootelian and Gaedeke (1996), in another American study, reported that economic factors such as monthly charges and interest rates on deposits weigh heavily on students' decisions concerning banking patronage.

In New Zealand, Thwaites, Brooksbank and Hanson (1997) found that fast and efficient service, friendly and helpful staff and reputation of the bank are important factors in the selection of a bank. Some students were found to be sensitive to the core services offered, some were conscious of every aspect of their banks and some others would shop around for the best deal.

In Singapore, Huu and Kar (2000) found that undergraduates place high emphasis on the pricing and product dimensions of bank services. Where as, the third party influences were found to be the least important selection criteria. Gerrard and Cunningham (2001) found that the most important dimensions in bank selection are "feel secure", followed by "electronic services" and "service provision". Consistent with the findings of Huu and Kar (2000), the "third party influences" was found to be the least important dimension.

In a survey conducted in Bahrain, Almossawi (2001) found that the key attributes determining college students' bank selection were: bank's reputation, availability of parking space near the bank, friendliness of bank personnel and availability and location of ATM. In Bosnia-Herzegovina, Cicic, Brkic and Agic (2004) identified the following attributes as the major determinants of bank selection among undergraduate students: reception at the bank, friendliness of bank personnel, low services charges, ease of opening a current account, and confidence in bank management.

In Tanzania, Ishemoi (2007) found that service quality was the most important criteria prioritized by students in their bank selection process. The factor was followed by financial factors comprising of attributes like low service charges and low interest rate charged by the bank. Delivery system comprising of attributes like absence of queues and availability of ATMs were also highly ranked.

In a cross-national study of students' selection of retail banks in the USA, Taiwan and Ghana, Blankson, Cheng and Spears (2007) identified three key factors, namely convenience, competence and free banking (no bank charges), to be consistent across the three countries. A similar study undertaken by Blankson, Omar and Cheng (2009) in the USA and Ghana found four key factors namely convenience, competence, recommendation by parents, and free banking and/or no bank charges, to be consistent across the two economies.

In an unpublished master thesis, Rhee (2009) reported that the availability of internet banking, the financial stability of the bank, bank reputation, provision of fast and efficient service and low service charges were of paramount importance to Dutch students when they choose a bank. Other banking attributes relating to the availability of parking space, overdraft facility, 


\section{Macrothink}

Journal of Management Research

ISSN 1941-899X

2011, Vol. 3, No. 2: E14

advertising, credit card limit and free gift incentives were found to be the least important selection criteria.

Rao and Sharma (2010) investigated 312 MBA sudents in Delhi, India, to identify the various factors that affect their bank selection decisions. The researchers factor-analyzed the data and identified six major factors influencing students' choice of a retail bank: reliability, convenience, assurance, value added services, accessibility and responsiveness.

Chigamba and Fatoki (2011) conducted a similar study to identify factors determining the choice of commercial banks by university students in South Africa. A total sample of 186 students from the University of Fort Hare (Alice campus) was surveyed in the study. The researchers found that the key factors determining university students' bank choice (in their order of importance) were: service, proximity, attractiveness, recommendations, marketing and price.

Katircioglu, Fethi, Unlucan and Dalci (2011) investigated the bank selection criteria of undergraduate students in North Cyprus by comparing the selection factors between Turkish and non-Turkish international students. Availability and convenient location of ATM services" and "speed and quality of service" were found to be the most crucial factors for considering banks and their services for both Turkish and non-Turkish students. 
Table 1. Overview of previous studies.

\begin{tabular}{|c|c|c|}
\hline Researcher(s) & Country & Primary attributes affecting students' bank selection \\
\hline Lewis (1982) & UK & Convenience of location to college, parental advice \\
\hline $\begin{array}{l}\text { Thwaites \& Vere } \\
\text { (1995) }\end{array}$ & UK & $\begin{array}{l}\text { Proximity of an ATM to college, free banking service, } \\
\text { overall student offer }\end{array}$ \\
\hline $\begin{array}{l}\text { Tootelian \& } \\
\text { Gaedeke (1996) }\end{array}$ & USA & Monthly charges, interest rates on deposits \\
\hline $\begin{array}{l}\text { Thwaites, } \\
\text { Brooksbank \& } \\
\text { Hanson (1997) }\end{array}$ & New Zealand & $\begin{array}{l}\text { Fast and efficient service, friendly and helpful staff, } \\
\text { reputation of the bank }\end{array}$ \\
\hline Schram (1991) & USA & Convenience, family tradition \\
\hline $\begin{array}{l}\text { Khazeh \& Decker } \\
(1992-93)\end{array}$ & USA & $\begin{array}{l}\text { Service charge policy, bank reputation, interest rates charged } \\
\text { on loans, loan approval times, friendly tellers }\end{array}$ \\
\hline Rhee (2009) & Netherland & $\begin{array}{l}\text { Internet banking, financial stability, bank reputation, the } \\
\text { provision of fast and efficient service, low service charges }\end{array}$ \\
\hline Huu \& Karr (2000) & Singapore & Pricing, product dimensions of bank services \\
\hline $\begin{array}{l}\text { Gerrard \& } \\
\text { Cunningham (2001) }\end{array}$ & Singapore & Feel secure, electronic services, service provision \\
\hline Almossawi (2001) & Bahrain & $\begin{array}{l}\text { Convenient ATM locations, availability of ATM in several } \\
\text { locations; bank reputation, 24-hours availability of ATM } \\
\text { services, availability of nearby parking space }\end{array}$ \\
\hline $\begin{array}{l}\text { Cicic, Brkic \& Agic } \\
(2004)\end{array}$ & $\begin{array}{l}\text { Bosnia } \\
\text { Herzegovina }\end{array}$ & $\begin{array}{l}\text { Reception at the bank, friendliness of bank personnel, low } \\
\text { services charges, ease of opening a current account, } \\
\text { confidence in bank management }\end{array}$ \\
\hline Tank \& Tyler (2005) & UK & $\begin{array}{l}\text { Recommendations, reputation/image, level of interest rates, } \\
\text { free cash incentives, ease of account opening }\end{array}$ \\
\hline Ishemoi (2007) & Tanzania & Service quality, financial factors, delivery system \\
\hline $\begin{array}{l}\text { Blankson, Cheng \& } \\
\text { Spears (2007) }\end{array}$ & $\begin{array}{l}\text { USA, Taiwan, } \\
\text { Ghana }\end{array}$ & Convenience, competence, free banking (no bank charges) \\
\hline $\begin{array}{l}\text { Blankson, Omar \& } \\
\text { Cheng (2009) }\end{array}$ & USA, Ghana & $\begin{array}{l}\text { Convenience, competence, recommendation by parents, free } \\
\text { banking }\end{array}$ \\
\hline $\begin{array}{l}\text { Rao \& Sharma } \\
(2010)\end{array}$ & India & $\begin{array}{l}\text { Reliability, convenience, assurance, value added services, } \\
\text { accessibility and responsiveness }\end{array}$ \\
\hline $\begin{array}{l}\text { Chigamba \& Fatoki } \\
\text { (2011) }\end{array}$ & South Africa & $\begin{array}{l}\text { Service, proximity, attractiveness, recommendations, } \\
\text { marketing, price }\end{array}$ \\
\hline $\begin{array}{l}\text { Katircioglu, Fethi, } \\
\text { Unlucan, \& Dalci } \\
\text { (2011) }\end{array}$ & North Cyprus & $\begin{array}{l}\text { Availability and convenient location of ATM services, } \\
\text { speed and quality of service }\end{array}$ \\
\hline
\end{tabular}

As demonstrated in the above discussion, factors considered important by young consumers when selecting their banks varies across countries and cultures (refer to Table 1 for a summary of previous studies). Although such studies have contributed to the development literature by providing valuable insights into bank choice criteria of young consumers, it should be pointed out that their findings may not be wholly applicable to other countries due to differences in economic, cultural and banking systems. This study strive to shed some light on students' selection of retail banks in the Malaysian context, which has not been given 
sufficient attention in the literature. This study is therefore a contribution to the marketing literature in this area.

\section{Research Methodology}

\subsection{The questionnaire}

A three-part questionnaire was used to collect data from the participants on bank selection criteria, banking behavior and demographics. The questionnaire had a short introduction which stated that the research was about students' bank selection criteria. In Section I, the participants were asked to rate the relative importance of thirty two potential influencing factors regarding their selection decision of commercial bank. These statements are developed based on past literature (e.g. Thwaites \& Vere, 1995; Almossawi, 2001; Gerrard \& Cunningham, 2001). Responses were measured using a five point Likert scale ranging from 1 ("not at all important") to 5 ("very important"). To counterbalance possible order-effect bias, no significance was placed on the order of the attributes in the questionnaire.

Section II of the questionnaire sought to obtain information on the banking behavior of the participants. The participants were asked for the name of banks at which savings accounts were maintained. The length of time that customers have been with their banks was also measured. To obtain personal background of the participants, questions regarding their gender, age, ethnicity, faculties and course studied were included in Section III of the questionnaire. The compiled questionnaire was pretested with 20 students, and comments were encouraged during the completion of the questionnaire. This led to some minor changes being made to the instrument (mainly in terms of phrasing and sequencing of the questions to improve clarity).

\subsection{The sample}

For the purpose of this study, undergraduate students of Universiti Malaysia Terengganu were taken as study sample. The whole population of undergraduates at the university's campus is estimated at 6,200 students. According to standards reported by Krejcie and Morgan (1970), the minimum sample size suggested for a population of 7,000 is 364 or $5.2 \%$ of the population.

A self-administered questionnaire was distributed to a non-probability sample of 500 full-time undergraduate students. Although the sample is selected on the basis of convenience and ease, data were gathered at different locations (classrooms and faculties), on different days of the week, and at different times of the day, thus reducing location and timing biases. Surveys were collected immediately upon completion, which yielded a total of 482 usable questionnaires, which was considered to be adequate to represent the population (Krecjie \& Morgan, 1970).

The responses obtained were analyzed using SPSS. Of the 482 respondents, $61 \%$ were females. The median age of respondents is 21.8 years $( \pm$ s.d. 1.32$)$. In terms of ethnic group, $55.8 \%$ of the respondents were Malay, $26.8 \%$ were Chinese and $17.4 \%$ were Indian.

\section{Data Analysis and Results}

\subsection{One-sample t-test}

The results of one-sample t-test analysis on the 32 bank selection items are shown in Table 2 . It was discovered that 25 items had a p-value (0.001) less than 0.05 , indicating that bank 
selection criteria were rated high in importance by the students. In other words, the majority of the variables are effective in consumer bank selection decision. The five most influential attributes in descending order for bank selection were: convenience in ATM locations, confidentiality, 24 hours ATM service, and availability of ATM in several locations. On the other hand, the least important five attributes determining students' selection of their banks were found to be: interior décor of building, class of people who patronize the bank, recommendations of friends, reception at the bank and influence of lecturers.

Table 2. One-sample statistics for individual attributes in consumer bank selection.

\begin{tabular}{|l|c|c|c|c|}
\hline & & \multicolumn{2}{|c|}{$\mu$ test value $=3$} & Ranking \\
\cline { 3 - 4 } Attribute & Mean & t-value & Sig. $(p)$ & mean \\
\hline Convenience ATM locations & 4.722 & 60.674 & .000 & 1 \\
Confidentiality & 4.635 & 47.753 & .000 & 2 \\
Financial stability of the bank & 4.608 & 50.090 & .000 & 3 \\
24 hours of ATM service & 4.550 & 45.673 & .000 & 4 \\
Availability of ATM in several & & & .000 & 5 \\
locations & 4.520 & 48.784 & & \\
Adequate service & 4.430 & 45.326 & .000 & \\
Friendliness of bank personnel & 4.429 & 38.333 & .000 & \\
Proximity to university & 4.419 & 39.493 & .000 & \\
Low service charge & 4.370 & 33.160 & .000 & \\
Adequate number of tellers & 4.299 & 34.854 & .000 & \\
Variability of services offered & 4.276 & 34.022 & .000 & \\
Professionalism of bank staffs & 4.243 & 33.315 & .000 & \\
Pleasant bank atmosphere & 4.220 & 31.015 & .001 & \\
Convenient location of main branch & 4.156 & 28.200 & .000 & \\
Several branches & 4.131 & 30.729 & .000 & \\
Convenient branch locations & 4.129 & 30.555 & .000 & \\
Regular bank statement & 4.160 & 32.040 & .000 & \\
The area of parking space & 4.064 & 26.750 & .000 & \\
Proximity to home & 4.056 & 24.037 & .000 & \\
Internet banking & 3.824 & 18.491 & .000 & \\
Free gifts to customers & 3.635 & 13.109 & .000 & \\
Influence of parents & 3.515 & 11.887 & .000 & \\
Appearance and attire of bank staffs & 3.483 & 11.518 & .000 & \\
Influential marketing campaign & 3.454 & 10.273 & .000 & \\
Low interest rates on loans & 3.227 & 26.684 & .000 & \\
Attractiveness of bank building & 3.077 & 1.590 & .112 & \\
Recommendations of relatives & 3.033 & 0.800 & .424 & \\
Interior décor of building & 3.025 & 0.530 & .596 & 28 \\
Class of people who patronize the bank & 2.996 & -0.088 & .930 & 29 \\
Recommendations of friends & 2.969 & -0.717 & .474 & 30 \\
Reception at the bank & 2.942 & -1.134 & .257 & 31 \\
Influence of lecturers & 2.815 & -1.912 & .328 & 32 \\
\hline Non: & & \\
& & \\
& & & \\
& &
\end{tabular}

Notes: Mean values - scoring: $1=$ not at all important; $5=$ very important

Ranking means in descending order

\subsection{Exploratory factor analysis}

Exploratory factor analysis with a varimax rotation was used to analyze the interrelationships 
among variables (bank selection criteria). Items with factor loadings above 0.4 and eigenvalues greater than one were retained (Hair et al., 1998). Variables with similar loadings on more than one factor were deleted (Hair et al., 1998), as were items that did not conceptually belong to the factor. Coefficient alphas and item-to-total correlations were computed each time items were deleted.

Table 3. Factor analysis.

\begin{tabular}{|c|c|c|c|}
\hline Factor & Label & Banking attributes & Factor loading \\
\hline 1 & Attractiveness & $\begin{array}{l}\text { Interior décor of building } \\
\text { Attractiveness of bank building } \\
\text { Appearance and attire of staff } \\
\text { Class of people who patronize the bank } \\
\text { Pleasant bank atmosphere }\end{array}$ & $\begin{array}{l}0.800 \\
0.797 \\
0.750 \\
0.547 \\
0.493\end{array}$ \\
\hline 2 & Recommendation & $\begin{array}{l}\text { Recommendations of relatives } \\
\text { Recommendations of friends } \\
\text { Recommendations of parents } \\
\text { Recommendations of lecturers } \\
\text { Reception at the bank }\end{array}$ & $\begin{array}{l}0.863 \\
0.833 \\
0.579 \\
0.570 \\
0.411\end{array}$ \\
\hline 3 & Service provision & $\begin{array}{l}\text { Regular bank statement } \\
\text { Professionalism of bank staff } \\
\text { Adequate service } \\
\text { Variability of service offered }\end{array}$ & $\begin{array}{l}0.828 \\
0.721 \\
0.591 \\
0.418\end{array}$ \\
\hline 4 & ATM service & $\begin{array}{l}\text { ATM in several locations } \\
24 \text { hours of ATM service } \\
\text { Convenience ATM locations }\end{array}$ & $\begin{array}{l}0.771 \\
0.746 \\
0.644 \\
\end{array}$ \\
\hline 5 & Sense of security & $\begin{array}{l}\text { Confidentiality } \\
\text { Financial stability of the bank }\end{array}$ & $\begin{array}{l}0.807 \\
0.745\end{array}$ \\
\hline 6 & Promotion & $\begin{array}{l}\text { Free gifts to customers } \\
\text { Influential marketing campaign }\end{array}$ & $\begin{array}{l}0.758 \\
0.726\end{array}$ \\
\hline 7 & Proximity & $\begin{array}{l}\text { Proximity to home } \\
\text { Proximity to university }\end{array}$ & $\begin{array}{l}0.870 \\
0.839\end{array}$ \\
\hline 8 & Location & $\begin{array}{l}\text { Convenient branch location } \\
\text { Several branches }\end{array}$ & $\begin{array}{l}0.840 \\
0.804\end{array}$ \\
\hline 9 & Financial benefits & $\begin{array}{l}\text { Low service charges } \\
\text { Low interest rates on loan }\end{array}$ & $\begin{array}{l}0.847 \\
0.700\end{array}$ \\
\hline
\end{tabular}

Note: Varimax rotation with Keiser normalization, loadings $<0.4$ omitted.

The results of the factor analysis are shown in Table 3. The factor analysis produced nine factor groups. Following a close inspection of the item on each factor, the nine factors were summarily named as follows: Attractiveness (5 items), Recommendation (5 items), Service Provision (4 items), ATM Service (3 items), Sense of Security (2 items), Marketing Promotion ( 2 items), Proximity (2 items), Branch Location (2 items) and Financial Benefits (2 items). Altogether these factors represent $63.6 \%$ of the variance, which satisfies the percentage of variance criterion for social science research (Hair et al. 1998). All factors were 
considered reliable as Cronbach alphas equal or greater than 0.5 are generally accepted as indicating adequate reliability (George \& Mallery, 2001, p. 217).

\subsection{Ranking importance of bank selection factors}

All nine factors ranked according to their importance by performing Friedman test, which is an alternative non-parametric to one-way analysis of variance (ANOVA). Friedman test was used for ANOVA when data were scaled on ordinal scale and provided by the same respondent (Norusis, 2008). Although it is not as powerful as a parametric test, increasing the sample size can increase its power to that approaching its parametric equivalents (Sekaran, 1992).

Table 4. Ranking of bank selection factors.

\begin{tabular}{|l|c|c|c|}
\hline Factor & $\begin{array}{c}\text { Arithmetic } \\
\text { mean* }\end{array}$ & $\begin{array}{c}\text { Mean } \\
\text { rank }\end{array}$ & $\begin{array}{c}\text { Importance } \\
\text { rank }\end{array}$ \\
\hline Sense of security & 4.671 & 7.169 & 1 \\
ATM service & 4.596 & 6.844 & 2 \\
Financial benefit & 4.292 & 5.845 & 3 \\
Service provision & 4.280 & 5.667 & 4 \\
Proximity & 4.238 & 5.734 & 5 \\
Location & 4.132 & 5.204 & 6 \\
Marketing promotion & 3.545 & 3.519 & 7 \\
Attractiveness & 3.360 & 2.908 & 8 \\
Recommendation & 3.055 & 2.109 & 9 \\
\hline Friedman Chi-square $=1643.263$ & & \\
Test: Degree of freedom $(\mathrm{df})=8$ & \\
\multicolumn{2}{|r}{ Asymp. Sig. $=0.000$} & \\
\hline
\end{tabular}

Notes: *Mean values - scoring: $1=$ not at all important; $5=$ very important

The results in Table 4 indicate some variation in the ranking of bank selection factors, which suggests that students are able to differentiate between various choice criteria. Higher value of scale means more importance assigned to bank selection factor. Sense of security was the most important factor in influencing the students in selecting a bank. ATM service was the second prioritized factor followed by financial benefits. The next three criteria, ranked fourth, fifth and sixth, respectively, were service provision, proximity, and location that can be grouped as moderate factors. Factors like marketing promotion, attractiveness and recommendation, which were ranked seventh, eighth and ninth, respectively, are perceived to be the least important criteria by the students.

The Friedman Test indicated highly significant differences in the importance of bank selection criteria $\left(\chi^{2}=1643.263, p=0.000\right)$, which implies that variations between the nine factors are likely to hold in the population. Thus we may infer that the ranking of importance among the selection criteria is statistically significant, thus the null hypothesis can be rejected. 


\section{Discussion}

Consistent with the results of Gerrard and Cunningham (2001) and Rhee (2009), the results indicated that the factor having the greatest influence on the students' bank selection decision was "sense of security". This finding coincides with the conventional wisdom that banking services involve more perceived risk due to the intangibility of the bank's products. One reason for this is consumers' high sense of insecurity (i.e. fears of divulging personal information, uncertainty about bank's stability and perceived financial and psychological risks that their deposits could be put in jeopardy by criminal deviance), which, despite the media coverage and the verbal and technical reassurances provided by the banking service providers, preys heavily on consumers' minds. With the advent of online banking services, the problem of risk has increased considerably and the need to feel secure would continue to be very important feature of students' bank selection process.

The second most important criterion rated by students was "ATM service". This is not unexpected, considering the fact that the current well-educated generation has been exposed to modern technology in their higher education. Prior to self-service technology becoming available, over-the-counter delivery of bank services was the common method of conducting banking business, as demonstrated by Lewis (1982). However, with the advent of self-service technologies, reliance on the branch has declined. It appears that, there is a strong desire for the young customers to make financial services available through the use of modern technology, not only for their convenience, speed and increased autonomy in executing the transactions, but also for the cognitive and sensory experiences they gained from using ATMs. The importance of this criterion has been seen in previous studies which have used students as their sample (Thwaites \& Vere, 1995; Gerrard \& Cunningham, 2001; Almossawi, 2001; Katircioglu et al. 2011).

The "financial benefits" which include low service charges and low interest rates on loan, was rated as the third most important criterion influencing students when deciding which bank to patronize. This finding exhibit some consistency with those of Khazeh and Decker (1992-93) who found that factors such as service charge policy and interest rates charged on loans were rated as influential for bank selection. Similarly, in Tank and Tyler's (2005) study, the 'level of interest rate' was ranked third out of the 19 criteria. This may be explained by the fact that university students in general have a greater knowledge about banking matters and are more aware of the financial benefits they can expect to gain from banking transaction.

The fourth most important criterion was "service provision", which includes regular bank statement, professionalism of bank staff, adequate service and variety of service offered. In Gerrard and Cunningham's (2001) study, the service provision factor was ranked third out of seven factors. The professionalism of bank staffs and the range of services that are available from banks are seen as being part of this factor group.

The "proximity" and "branch location" factors were ranked fifth and sixth, respectively, in this study. This finding suggest that locational convenience, which proved to be an influential factor in previous studies (Lewis, 1982; Schram, 1991), is no longer a major influence on the students' selection of a retail bank. This correlates with the recent findings of Tank and Tyler 
(2005) that technological advances have eradicated the previous importance placed on locational convenience. As mentioned earlier, students are tending to rely increasingly on the availability of ATM service (ranked second in this study), and therefore far less reliance needs to be placed on the proximity of the nearest branch to home/university. The fact that the proximity of a bank to the home/university is far less important than the availability of ATMs at convenience location supports the view that university students have relatively simple financial needs (Thwaites \& Vere, 1995) and are more prefer to conduct transactions electronically away from the branch counter (Gerrard \& Cunningham, 2001; Tank \& Tyler, 2005; Katircioglu et al. 2011).

The "marketing promotion" factor came next in terms of relative importance. It appears that, bank's marketing campaign is seen as less influential and unlikely to provide a major stimulus for choosing a bank. This is consistent with the findings of previous studies (Lewis, 1982; Huu \& Kar, 2000; Gerrard \& Cunningham, 2001; Tank \& Tyler, 2005; Rhee, 2009). Likewise, the "attractiveness" factor is not highly ranked by the students. This may be due to their simple financial needs and strong affinity for ATM; as a result, they are not particularly concerned with the physical image of the bank. Again, this finding is reflective of the results of Gerrard and Cunningham (2001). In that study, the bank's appearance (part of which involves the interior décor and attractiveness of bank buildings) was ranked sixth out of seven factors.

Finally, contrary to our naive expectations, the "recommendation" factor was found to be the least important criterion rated by the students. This was found to be the most important criterion reported in three previous studies (Lewis, 1982; Schram, 1991; Tank \& Tyler, 2005), but in all subsequent studies conducted in Asian setting (Huu \& Kar, 2000; Almossawi, 2001; Gerrard \& Cunningham, 2001), it has been rated as the least important criterion. This may indicate that students are more capable of making choice decisions by themselves because they are highly educated and are more confident to act independently rather than relying on the recommendations of others.

\section{Implications}

This paper aims to examine the major attributes considered most important by university students in the process of selecting a bank. The contribution of the article lies in achieving a more profound understanding of the factors underlying bank selection decisions of young intellectuals, and further, in offering suggestions and practical advice for service providers' decision-making. The results of the study reveal that some criteria are viewed as having more importance than other criteria. Based on comparison of means, ranking of factors influencing bank choice decision by importance are as follows: sense of security, ATM service, financial benefit, service provision, proximity, location, marketing promotion, attractiveness and recommendation.

The results provide useful insights into the nature of student bank selection with important implications for managerial decision making. By tailoring their marketing strategies to stress the satisfaction of the criteria mentioned above, bank marketers may be better able to influence the student segment. Bank marketers can now check how far they are providing 
their services in terms of customer orientation. With current strategies, are they serving the needs of student segment? What areas should they improve in order to provide better service offering to this segment? Findings from this study can help banking service providers develop a better marketing strategy in attracting and retaining students.

The main focus of any marketing campaign aimed at attracting students should be on making them feel secure by emphasizing the bank's long term stability and protection of the privacy and confidentiality of customers' information. Customer confidence and sense of security also can be increased through banking service quality cues. By incorporating elements that convey service quality determinants of assurance, reliability, empathy, responsiveness and tangibles into their service marketing, banks can increase perceived quality, and thus reduce consumers' feeling of insecurity (Chen \& Chang, 2005). Winning customer confidence will ensure a high probability of customers' loyalty and positive word-of-mouth communication, thus increasing its customer base.

To serve more efficiently the students' needs, particular attention must be given to ATM service quality. This includes aspects such as convenient and secured locations, functions of ATM, adequate number of machines and user-friendliness of the systems and procedures. ATM service should be able to provide enhanced interactivity, diversified offerings, and facilitate customers to participate in improving the service encounter with ATM and make it a memorable and pleasant experience. The banks should focus not only on the satisfaction of ATM users, but also aim at delighting them to ensure their retention (Khan, 2010). These facilities will not only provide time and locational convenience demanded by students, but also a lower cost method for the bank (Meister, 1996).

The results of this study further show that students tend to attach greater importance on financial benefits when choosing a bank to patronize. Thus, the offer of rewards and cash incentives of various types should prove successful in attracting this segment. These could be in the form of cash rebate, point redemption, discounts for certain services, higher interest rate on savings account balance or surcharge-free ATM service. In order to increase the chances of students and graduates staying with a bank, it may make sense to introduce a loyalty scheme, for instance, giving a loyalty bonus to graduates who stay with the bank for a certain period of time.

This study has several limitations that point to useful directions for future research. One main limitation is the use of a student sample. Although students are the most convenient respondents available to academic researchers and are considered appropriate for this study, taking a sample from one university may not be representative of the student population in general. In addition, the data was collected only in Malaysia; as such, the results and discussion are applicable particularly to the Malaysian context. Finally, it should be noted that selection criteria employed by other segments of young customers (e.g. working class Gen $\mathrm{Y}$ or fresh graduates who just joined the workforce) may have different selection processes than those of students. It is recommended that further research be undertaken using a nationally representative sample or in other cultural settings to establish the degree of generalizability of the current findings. 


\section{References}

Almossawi, M. (2001). Bank selection criteria employed by college students in Bahrain: an empirical analysis. International Journal of Bank Marketing, 19(3), 115-25.

Blankson, C., Cheng, J. M. S., \& Spears, N. (2007). Determinants of banks selection in USA, Taiwan and Ghana. International Journal of Bank Marketing, 25(7), 469-489.

Blankson, C., Omar, O. E. \& Cheng, J. M. S. (2009). Retail bank selection in developed and developing countries: A cross-national study of students' bank-selection criteria. Thunderbird International Business Review, 51(2), 183-198.

Chen, T. Y. \& Chang, H. S. (2005). Reducing consumers' perceived risk through banking service quality cues in Taiwan. Journal of Business and Psychology, 19(4), 521-540.

Chigamba, C. \& Fatoki, O. (2011). Factors influencing the choice of commercial banks by university students in South Africa. International Journal of Business and Management, 6(6), 66-76.

Cicic, M., Brkic, N. \& Agic, E. (2004). Bank selection criteria employed by students in a southeastern European country: An empirical analysis of potential market segments' preferences. In J. Wiley \& P. Thirkell (Eds.), Marketing accountabilities and responsibilities: Proceedings of the ANZMAC 2004 Conference, Wellington, 29 Nov-1 Dec 2004. Australian \& New Zealand Marketing Academy.

Duncan, G. J., Smeeding, T. M. \& Rodgers, W. (1992). The incredible shrinking middle class. American Demographics, 14, 34-38.

Economic Planning Unit (2006). Malaysian Ninth Plan (2006-2010). Prime Minister Department, Putrajaya. Retrieved October 20, 2010 from http://www.epu.gov.my/html/themes/epu/html/rm9/english/Chapter16.pdf

George, D. \& Mallery, P. (2001). SPSS for Windows, 3rd ed. Allyn \& Bacon/Pearson Education Company.

Gerrard, P. \& Cunningham, J. B. (2001). Singapore undergraduates: how they choose which bank to patronise. International Journal of Bank Marketing, 19(3), 104-114.

Government of Malaysia (2001). Third Outline Perspective Plan 2000-2010. Government Printing.

Hair, J. F., Anderson, R. E., Tatham, R. L. \& Black, W. C. (1998). Multivariate Data Analysis, 5th ed. Upper Saddle River, NJ: Prentice Hall.

Huu, P. T. \& Kar, Y. H. (2000). A study of bank selection decisions in Singapore using the analytical hierarchy process. International Journal of Bank Marketing, 18(4), 170-180.

Ishemoi, L. J. (2007). Bank selection criteria among undergraduate students in Tanzania. The African Journal of Finance and Management, 15(2), 33-44.

Katircioglu, S. T., Fethi, S., Unlucan, D. \& Dalci, I. (2011). Bank selection factors in the 
banking industry: an empirical investigation from potential customers in northern Cyprus. Acta Oeconomica, 61(1), 77-89.

Khan, M. A. (2010). An empirical study of automated teller machine service quality and customer satisfaction in pakistani banks. European Journal of Social Sciences, 13(3), 333-344.

Khazeh, K. \& Decker, W. H. (1992-93). How customers choose banks. Journal of Retail Banking, 14(4), 41-44.

Krejcie, R. V. \& Morgan, D. W. (1970). Determining sample size for research activities. Educational and Psychological Measurement, 30(3), 607-610.

Lewis, B. R. (1982). Student accounts - a profitable segment. European Journal of Marketing, 16(3), 63-72.

Ministry of Higher Education Malaysia (2009). Statistics of Higher Education Malaysia 2009. Retrieved October 24, 2010 from http://www.mohe.gov.my/web_statistik/satistik_2009.htm

Meister, C. K. (1996). Converging trends portend dynamic changes on the banking horizon. Bank Marketing, 28(7), 15-21.

Nielsen (2010). Saving a top priority for Chinese... but why? Understanding the motivations behind China's high savings rate. The Nielsen Company. October 2010.

Norusis, M. J. (2008). SPSS 16.0 Advanced Statistical Procedures Companion. Englewood Cliffs, NJ: Prentice-Hall.

Rao, A. S. \& Sharma, R. K. (2010). Bank selection criteria employed by MBA students in Delhi: an empirical analysis. Journal of Business Studies Quarterly, 1(2), 56-69.

Rhee, J. V. D. (2009). How do Dutch students choose their banks? A cross-cultural comparison. Unpublished Master Thesis. Erasmus University Rotterdam.

Sabri, M. F. \& Masud, J. (2002). Sosialisasi kewangan di kalangan remaja [Financial socilization among adolescents]. Malaysian Journal of Consumer and Family Economics, 5, 21-32.

Sekaran, U. (1992). Research Methods for Business. New York: John Wiley and Sons, Inc.

Schram, J. (1991). How student choose their banks. US Banker, 110, 75-78.

Tank, J. \& Tyler, K. (2005). UK student banking revisited: influences and the decision-making process. Journal of Financial Services Marketing, 10(2), 152-164.

Thwaites, D., Brooksbank, R. \& Hanson, A. (1997). Bank selection criteria in New Zealand: a student perspective. New Zealand Journal of Business, 19(1\&2), 95-107.

Thwaites, D. \& Vere, L. (1995). Bank selection criteria: a student perspective. Journal of Marketing Management, 11, 133-149.

Tootelian, D. H. \& Gaedeke, R. M. (1996). Targeting the college market for banking services. Journal of Professional Services Marketing, 14(2), 161-172. 